\title{
ANTROPOLOGICZNE ASPEKTY REKONSTRUKCJONIZMU ŻYDOWSKIEGO
}

Wszelkie rozważania na temat antropologii żydowskiej domagają się uprzedniego wyjaśnienia fenomenu myśli żydowskiej w ogóle. Nie jest bowiem jasne i oczywiste stwierdzenie, co oznacza określenie „żydowski". Od strony podmiotowej nie wystarczy, że myśliciel jest Żydem. W samym środowisku żydowskim stosuje się różne kryteria uznawania kogoś za Żyda (jedno z rodziców jest Żydem, matka jest Żydówką, wystarczy poczucie bycia Żydem). Pomijając kontrowersje z tym związane, o wiele poważniejszy jest problem od strony przedmiotowej. Nie każdy bowiem Żyd odzwierciedla żydowski sposób myślenia. Trudno bowiem uznać za żydowskie poglądy, które są chrześcijańskie lub marksistowskie, nawet jeśli ich autorami są Żydzi. Powstaje zasadne pytanie, co stanowi o żydowskości kogoś lub czegoś. W starożytności i w średniowieczu tym kryterium była religia żydowska. Każdy Żyd był uznawany za wyznawcę judaizmu i odwrotnie. Dziś już tak nie jest. W przeszłości termin „żydowski” oznaczał ,judaistyczny”. Obecnie ma wiele znaczeń.

* Ks. dr hab. Waldemar Szczerbiński, prof. UAM jest kierownikiem Zakładu Kultury Judaizmu Instytutu Kultury Europejskiej UAM w Poznaniu. 
Współczesna myśl żydowska w znacznej mierze stanowi odzwierciedlenie kryzysu, który jest wynikiem konfliktu między tradycyjnym judaizmem a świeckim liberalizem. W Stanach Zjednoczonych pojawił się ruch żydowski - rekonstrukcjonizm, którego głównym celem było zażegnanie tego kryzysu. Kaplan jako założyciel tego nurtu stwierdził wprost, że jest to ,jedyna alternatywa dla ortodoksji i sekularyzmu"1. Rekonstrukcjonizm formułując nowoczesną ideologię naukową, która oparta jest na założeniu, że judaizm nie jest religią, lecz rozwijającą się cywilizacją religijną, chciał przystosować świat żydowski do naukowego klimatu naszych dni².

Tradycyjny judaizm, zwany obecnie teizmem żydowskim, reprezentowany jest $\mathrm{w}$ większym lub mniejszym stopniu przez ortodoksów, reformatorów i konserwatystów ${ }^{3}$. Wymienione denominacje, pomimo różnic, utrzymują wciąż tradycyjne rozumienie judaizmu i żydowskich prawd wiary. Budowanie przez Kaplana nowej wizji judaizmu poprzedzone jest krytyką wspomnianych wyżej grup ${ }^{4}$. Według Kaplana, teistyczny judaizm, który był charakterystyczny dla przeszłości i wciąż bezzasadnie podtrzymywany, jest nie do przyjęcia dla współczesnego Żyda. Dlatego wyłoniła się potrzeba chwili, aby głoszone od wieków zasady zrekonstruować i to w taki sposób, który uwzględniałby zarówno tradycję, jak i osiągnięcia nowożytnej nauki. Aby osiągnąć ów cel, należy,

${ }^{1}$ M. Kaplan, Judaism without Supernaturalism, New York 1958, wstęp.

${ }^{2}$ Obszerna prezentacja rekonstrukcjonizmu żydowskiego znajduje się w: Reconstructionism, w: Encyklopedia Judaica, t. 13, Jerusalem 1971, kol. 1615-1617; M. M. Kaplan, The Future of the American Jew, New York 1967; tenże, Judaism as a Civilization. Toward a Reconstruction of American-Jewish Life, Philadelphia and New York 1981; R. T. Alpert, J. J. Staub, Exploring Judaism. A Rekonstructionist Approach, Elkins Park, PA 2000; H. M. Schulweis, Reconstructionism, w: A. A. Cohen, P. Mendes-Flohr (red.), Contemporary Jewish Religious Thought, New York 1988, s. 755-759; A. M. Eisen, Rethinking Modern Judaism, Chicago and London 1998, s. 216-241. W języku polskim opracowanie tego nurtu znajduje się w: W. Szczerbiński, Postulat nie-osobowego Boga. Rekonstrukcjonizm wyzwaniem dla teizmu żydowskiego, Poznań 2007.

${ }^{3}$ Ortodoksja stoi na stanowisku, że niczego nie można zmienić. Reforma pragnie zmienić wszystko w oparciu jedynie o sumienie jednostki. Ruch konserwatywny opowiada się za częściowymi zmianami, o których może decydować tylko wspólnota, a nie poszczególny człowiek. Sami Żydzi opisują te grupy jako: crazy (szaleni) - judaizm ortodoksyjny; lazy (leniwi) - judaizm reformowany; hazy (zamglony) - judaizm konserwatywny.

${ }^{4}$ Zob. M. M. Kaplan, Judaism as a Civilization, s. 91-169. 
jak postulowal5, wniknąć w inspiracje tradycji żydowskiej i podtrzymać jej siłę; zreinterpretować tkwiące w tradycji fakty, wartości, historię, literaturę za pomocą pojęć współczesnej nauki; postrzegać judaizm jako ustawicznie rozwijającą się religijną cywilizację, unikając jednocześnie błędu dychotomii między tym, co świeckie, a tym, co religijne; położyć społeczne i duchowe fundamenty pod organicznie demokratyczne funkcjonowanie wspólnoty żydowskiej i jej różnych instytucji; zaszczepić w grupach żydowskich nową moc twórczą, która pozwoli im odkryć w judaizmie standardy nauki, moralności i wszelkich wartości; dodać duchowego znaczenia i motywacji życiu jednostki i grupy; odnieść życie wspólnoty żydowskiej do społeczeństwa amerykańskiego i spraw światowych.

Istotą judaizmu tradycyjnego było przeniknięcie wszystkiego religią, uczynienie sacrum z profanum. Haskala dążyła do ograniczenia tej dominacji poprzez wyznaczenie religii jej miejsca i wyodrębnienie świeckiej - humanistycznej rzeczywistości żydowskiej. Kaplan nie odrzucał tradycji. Kierując się zasadami haskali, krytykował wszelki dogmatyzm i nietolerancję, dążył do reinterpretacji teizmu żydowskiego. W przeszłości zmiany, które dokonywały się w judaizmie, były nieznaczne i nieistotne $\mathrm{w}$ porównaniu z radykalną modyfikacją, której dokonał Kaplan. Dla religijnych Żydów jakiejkolwiek przynależności z pewnością najbardziej kontrowersyjnym aspektem myśli Kaplana była jego antyantropomorficzna, antypersonalistyczna i antysupernaturalistyczna koncepcja Boga, z której wynikały wszelkie inne przekonania ${ }^{6}$.

Pierwsze pytanie, które stawiamy w odniesieniu do systemu myśli, dotyczy metodologii zastosowanej przez danego autora. Kaplan dostrzega w pragmatyzmie metodę filozoficzną, dążącą do wypracowania myśli, która byłaby znacząca i odpowiadałaby potrzebom człowieka ${ }^{7}$. „Aby jakakolwiek idea miała znaczenie, musi być widziana w kontekście warunków naturalnych i związków międzyludzkich"8. Jak widać, za konieczny

${ }^{5}$ Zob. I. S. Chipkin, Dr. Mordecai M. Kaplan and Jewish Education, w: I. Eisenstein, E. Kohn (red.), Mordecai M. Kaplan: An Evaluation, New York 1952, s. 92.

${ }^{6}$ Por. R. M. Seltzer, Kaplan and Jewish Modernisty, w: E. S. Goldsmith, M. Scult, R. M. Seltzer (red.), The American Judaism of Mordecai M. Kaplan, New York-London 1990, s. 10.

7 Por. W. E. Kaufman, The Contemporary Relevance of Mordecai M. Kaplan's Philosophy, "Conservative Judaism” 4 (1981), s. 11.

8 "Any idea, to have meaning, must be seen in a context of natural conditions and human relations". M. M. Kaplan, The Way I Have Come, w: I. Eisenstein, E. Kohn (red.), Mordecai M. Kaplan: An Evaluation, New York 1952, s. 299. 
warunek ważności (prawdziwości) myśli uznaje Kaplan możliwość jej zastosowania w praktyce. Kluczem do zrozumienia teorii Kaplana ${ }^{9}$ jest holistyczne ${ }^{10}$ i organizmiczne ${ }^{11}$ myślenie dostarczające wglądów, które prowadzą go do pojmowania judaizmu jako totalnej cywilizacji. Czytamy bowiem, że „właściwe widzenie judaizmu jako całości, stąd jako czegoś więcej niż religii, które jest wynikiem najnowszej perspektywy, jaką umysł ludzki jest w stanie osiągnąć, stało się możliwe dzięki holistycznemu i organizmicznemu myśleniu"12. Można powiedzieć, że taka metoda ma zmierzać do adaptacji judaizmu, a nie do jego konserwacji.

„Metoda, którą posługiwali się starożytni, może być nazwana transwaluacją ${ }^{13}$; metodę, która musimy się posługiwać możemy nazwać rewaluacją ${ }^{14115}$. W opinii Kaplana transwaluacja jest charakterystyczna dla tradycyjnego judaizmu, który stosował ją jako narzędzie umożliwiające

${ }^{9}$ Kaplan używa terminów holistic (holistyczny) i organismic (organizmiczny). Należy te pojęcia odróżnić od organic (organiczny).

${ }^{10}$ Holizm - finalistyczna teoria rozwoju nawiązująca do bergsonowskiego emergentyzmu i dynamizmu. Traktuje wszechświat jako całość, na którą składają się rozwijające się dynamicznie części. Wynikiem tej ewolucji są nowe części i nowe jakości. Holizm jako metoda postuluje rozpatrywanie zjawisk jako części jakiejś całości. W szczególności neguje możliwość atomizowania tych fragmentów rzeczywistości, które odnoszą się do organizmów żywych, zjawisk psychicznych i społecznych oraz różnych form organizacji. W holizmie zachowanie się lub naturę składników tłumaczy się swoistością całości, którą tworzą, a która przekracza to, co jest w składnikach.

${ }^{11}$ Organicyzm lub organizmalizm - stanowisko, według którego cała przyroda lub wyodrębniony fragment rzeczywistości stanowi całość funkcjonującą w podobny sposób jak żywy organizm i tworzy odrębne struktury organiczne podlegające swoistym prawom. W socjologii jest to kierunek głoszący, że społeczeństwo, będąc częścią przyrody, spełnia te same funkcje, co organizmy biologiczne wyższego rzędu. Organicyzm podporządkował społeczeństwo jako fragment rzeczywistości przyrodniczej prawom rządzącym życiem organicznym.

12 "seeing Judaism as totality, and therefore as more than a religion, was made possible as a result of the latest perspective which the human mind has been able to achieve - that of holistic or organismic thinking". M. M. Kaplan, Judaism as a Civilization, s. XI. Książka zawiera dwa wstępy. Cytowany fragment pochodzi ze wstępu do wydania z 1967 roku, który również został umieszczony w wydaniu z 1981 roku.

${ }^{13}$ Transvaluation - transwaluacja lub transwaloryzacja. Chodzi o przewartościowanie lub nadanie nowej wartości (przekształcenie wartości).

${ }^{14}$ Revaluation - rewaluacja lub rewaloryzacja. Należy to rozumieć jako powrót do pierwotnej wartości lub przywrócenie wartości.

15 "The method which the ancients employed may be termed transvaluation; the method we must employ may be termed revaluation". M. M. Kaplan, The Meaning of God in Modern Jewish Religion, New York 1962, s. 3. 
religii żydowskiej zachowanie ciągłości ${ }^{16}$. Jego zdaniem, zarówno tradycja wyartykułowana w okresie rabinicznym, jak i przez późniejszych alegorystów żydowskich nadawała nowe znaczenia i wartości pierwotnym tekstom judaizmu. Według Kaplana, dokonująca się przez wieki transwaluacja nie jest możliwa dzisiaj. Wprost stwierdza: „Metoda transwaluacji nie może odgrywać takiej samej roli dla współczesnego Żyda"17. Troska o zachowanie ciągłości judaizmu współczesnego z judaizmem czasów przeszłych lub też przejście od judaizmu tradycyjnego do judaizmu przyszłości „może być osiągnięte jedynie w pełnym świetle całkowitej świadomości zmiany, w którą uwikłany jest judaizm"18. Rozwój nauki zmienił naszą świadomość i poszerzył nasze możliwości poznawcze. Dotyczy to również dziedziny religii. Jak sugeruje Kaplan, dziś wiemy, że właściwych znaczeń, sensów i wartości nie można szukać w narosłej tradycji, lecz w pierwotnych źródłach judaizmu. „Z tego powodu musimy odrzucić transwaluację i uciec się do rewaluacji"19. Transwaluacja jest powielaniem tego, co już było $\mathrm{w}$ nowej oprawie, a co nie jest możliwe do realizacji obecnie. „Rewaluacja polega na wyodrębnieniu z tradycyjnej treści tych elementów, które odpowiadają permanentnym postulatom natury ludzkiej oraz na integrowaniu ich z naszą własną ideologią"20. Jak wyjaśnia Kaplan dalej: „Kiedy dokonujemy rewaluacji, analizujemy lub rozkładamy na czynniki pierwsze wartości tradycyjne w ich całościowej zawartości, które mogą pomóc nam dostrzec nasze własne potrzeby moralne i duchowe; reszta może zostać oddana z powrotem archeologii" $^{\prime 21}$. Dodatkowo, rewaluacja idei religijnej lub instytucji religijnej może

${ }^{16}$ Kaplan utrzymywał, że odniesienia rabiniczne do tekstu pisanego (Tory) ujawniają dość dużą niezgodność z literalnym znaczeniem tekstu. Aby temu zapobiec, należy poddać badaniom oryginalne źródła tradycji żydowskiej. Zob. M. M. Kaplan, The Meaning of God in, s. 3-4.

17 "But the method of transvaluation cannot do that for the modern Jew". Tamże, s. 6.

18 "Can be effected only in the glaring light of complete awareness of the change involved". Tamże.

19 "For that reason we have to avoid transvaluation and resort to revaluation". Tamże.

20 "Revaluation consists in disengaging from the traditional content those elements in it which answer permanent postulate of human nature, and in integrating them into our own ideology". Tamże.

${ }^{21}$ "When we revaluate, we analyze or break up the traditional values into their implications, and single out for acceptance those implications which can help us met our own mora land spiritual needs; the rest may be relegated to archeology". Tamże. 
dokonać się tylko poprzez zrozumienie tychże fenomenów w świetle całościowej sytuacji, której były częścią22.

Kaplan miał własne rozumienie „najwyższego pojmowalnego celu" ludzkiej egzystencji. Tym celem jest pomoc w stworzeniu społeczności, które wychowa osoby zmotywowane przez to, co nazwał sensem aktywnej odpowiedzialności moralnej. „Dla nas Żydów” - pisał - „nie może istnieć żaden wyższy cel niż odzwierciedlanie sztuki życia, indywidualnie i zbiorowo, tak, aby wnieść swój udział w intelektualny, moralny i duchowy postęp ludzkości [...]. Typ religii, którego my Żydzi jako lud i ludzkość, jako całość niezmiernie potrzebujemy jako środka do przetrwania, musi przybrać taką formę, która umożliwi moralną odpowiedzialność w działaniu" ${ }^{\prime 23}$. W przekonaniu Kaplana, taki rodzaj religii pomógłby ludzkości uwolnić się od trzech iluzji, które jej zagrażają w czasach współczesnych: 1) iluzji kolektywizmu, 2) iluzji nieugiętego indywidualizmu, 3) iluzji niezmienności natury ludzkiej ${ }^{24}$. W terminach filozofii współczesnej judaizm $\mathrm{w}$ rozumieniu rekonstrukcjonistów jest egzystencjalnie ludem żydowskim, esencjalnie religią żydowską, funkcjonalnie żydowskim sposobem życia ${ }^{25}$.

Całkowicie nowym fenomenem w myśli żydowskiej jest rekonstrukcjonistyczna "teologia transnaturalna”, której zamiarem jest „zbudowanie teologii filozoficznej, która unika zarówno supernaturalizmu jak i naturalizmu redukcyjnego ${ }^{\prime 26}$. Można śmiało stwierdzić, że to stanowi dla Kaplana punkt wyjścia dla całego systemu myśli. Punkt wyjścia rozumiany jest zazwyczaj albo jako pierwsza czynność, albo jako pierwsza teza ${ }^{27}$. Pierwszą czynnością jest u Kaplana właśnie odrzucenie supernaturalizmu

${ }^{22}$ Zob. tamże, s. 7.

23 "For us Jews, there can be no higher purpose than that of exemplifying the art of so living individually and collectively as to contribute to the intellectual, moral, and spiritual progress of mankind [...]. The type of religion which we Jews as a people, and which mankind as a whole, urgently needs as a means to survival has to consist, or take the form of moral responsibility in action" - M. M. Kaplan, The Purpose and Meaning of Jewish Existence, Philadelphia 1964, s. 294.

${ }^{24}$ Por. E. S. Goldsmith, Kaplan and The Retrieval of the Haskalah, w: E. S. Goldsmith, M. Scult, R. M. Seltzer (red.), The American Judaism of Mordecai M. Kaplan, New York-London 1990, s. 22.

${ }^{25}$ Por. tamże, s. 24.

${ }^{26}$ W. E. Kaufman, The Transnatural Theology of Mordecai M. Kaplan, w: "Judaism" 1(1981), s. 45.

${ }^{27}$ U Kartezjusza pierwszą czynnością było wątpienie, a pierwsza tezą: cogito ergo sum. 
(nadnaturalności, nadprzyrodzoności). Pierwszą tezą jest natomiast: cogito ergo vivo ${ }^{28}$. Taki punkt wyjścia burzy fundament judaizmu tradycyjnego, którego podstawą w sensie czynności jest całkowita akceptacja objawienia, a w sensie pierwszej tezy jest: credo ergo vivo.

Na tle powyższych uwag łatwo dostrzec, że rekonstrukcjonistyczna antropologia jest rekonstrukcją antropologii tradycyjnego judaizmu. Wszystkie formy judaizmu teistycznego, mimo różnic interpretacyjnych, opierają swoje rozumienie człowieka na przekonaniu, że człowiek został stworzony przez osobowego Boga i na Jego podobieństwo. Przyjmują też prawdę o psychofizycznej jedności człowieka, zgodnie z którą każda istota ludzka ma zarazem ciało i duszę, element naturalny i nadnaturalny. W rekonstrukcjonizmie żydowskim człowiek uczestniczy w ustawicznym procesie stwarzania siebie w oparciu o nieosobowe siły w naturze, które zostały utożsamione z boskością. Dodatkowo ludzka bytowość została sprowadzona jedynie do dziedziny natury, którą każda jednostka może transcednować.

Pierwszym słownikowym znaczeniem terminu „transcendencja” jest: przekraczać, wznosić się, podnosić się, dźwigać się ponad lub poza ograniczenia i możliwości. Drugim znaczeniem jest: być transcendowanym do, odnosić się do celu lub przedmiotu transcendowania. Pierwsze znaczenie terminu - proces transcedowania - jest opisany w rekonstrukcjonizmie jako samo-transcendencja człowieka. „Istota osobowości leży w transcedowaniu siebie [...]. Nie ma żadnych ograniczeń w rozwinięciu osobowości; to obejmuje cały rodzaj ludzki jako całośćn"29. Podstawą koncepcji ludzkiej samo-transcendencji w systemie Kaplana jest wymiar wartości, który wyłania się jako odpowiedź na ludzkie potrzeby. Pierwszą i zasadniczą wartością jest dla niego odpowiedzialność, która wynika z ludzkiej potrzeby bycia potrzebnym innym. Kaplan ową potrzebę traktuje jako naturalną i jako samo-transcendującą. Jest ona naturalna, ponieważ wynika z psycho-społecznego popędu człowieka do wzajemnej relacji z innymi ludźmi. Jest samo-transcendująca, ponieważ spełnienie jej wymaga od człowieka przekroczenia siebie poprzez udział w odpowiedzialności zbiorowej za uwiecznienie grupy organicznej. W przekonaniu Kaplana, ta zdolność do samo-transcendencji jest znakiem osobowości zbiorowej. „Samo-świadomość, gdy jest zdrowa,

${ }^{28}$ Vivo (łac.) - w znaczeniu zostawać przy życiu, trwać, utrzymywać się, spędzać życie, żyć z kimś w zażyłości, być szczęśliwym.

${ }^{29}$ M. M. Kaplan, The Religion of Ethical Nationhood, New York 1972, s. 89. 
jest samo-transcendencją, gdy jest niezdrowa, jest samo-ograniczeniem i samo-zawężęniem" ${ }^{\prime 30}$.

Wzajemne oddziaływanie tego, co naturalne i tego, co samo-trascendujące prowadzi Kaplana do niespotykanej dotąd koncepcji tego, co trans-naturalne. Jak jego koncepcja człowieka obejmuje dynamiczną inter-relację między naturą ludzką a samo-transcendencją ludzką, tak też w swojej koncepcji boskości Kaplan usiłuje rozwinąć pojęcie boskiej transcendencji, która nie przekracza ograniczeń prawa naturalnego. Z tego powodu wprowadza określenie "trans-naturalność”, aby opisać Boga jako proces. "Jako proces kosmiczny, Bóg jest czymś więcej niż fizycznym, chemicznym, biologicznym, psychologicznym lub nawet społecznym procesem. Bóg zawiera wszystkie te procesy, lecz tym, co odróżnia Boga-proces jest to, że jest On super-faktyczny i super-doświadczalny. Tam, gdzie dodaje się supernaturalność, mijamy się całkowicie z tym punktem widzenia, skoro termin supernaturalny zakłada cud lub zawieszenie prawa natury. Z drugiej strony właściwe jest powiedzenie, że Bóg-proces jest trans-naturalny"31. Jak widzimy, Kaplan świadomie i stanowczo odrzuca nadprzyrodzoność. Twierdzi jednak, że Bóg-proces transcenduje i przekracza to, co ludzkie. Problemem jest rozstrzygnięcie, co dokładnie znaczy kaplanowski termin „trans-naturalny”. Kaplan wyraźnie nie akceptuje stanowiska, że Bóg transcenduje naturę jako odróżniony byt. Przeciwnie, taki pogląd wydaje mu się absurdalny. Klucz do wyjaśnienia tego zagadnienia leży w rozumieniu przedrostka „trans”32. Wśród różnych pospolitych wyjaśnieńn ${ }^{33}$ odnajdujemy też takie: „ustawicznie i tak, aby zmiana dokonała się całkowicie" ${ }^{\prime 34}$. W takim pryzmacie Bóg-proces jest procesem związanym z elementami kosmosu, który przenika przez elementy wszechświata, przemieniając go w nową organiczną całość ${ }^{35}$.

Trans-naturalizm zakłada koncepcję Boga jako procesu, który przenika naturę i przemienia ją z chaotycznego rozproszenia w dynamiczną, zrównoważoną, interaktywną rzeczywistość. Rekonstrukcjonistyczna koncepcja boskiej transcendencji odnosi się do twórczego aspektu natury,

${ }^{30}$ M. M. Kaplan, Not So Random Thoughts, New York 1966, s. 214.

${ }^{31}$ Tenże, The Future, s. 183.

${ }^{32}$ Por. W. E. Kaufman, The Concept of Transcendence in Reconstructionism, „Reconstructionist" 30 (1972), s. 8.

${ }^{33}$ Trans (łac.) - za, poza, $\mathrm{z}$ tamtej strony.

34 "Through and throught, so as to change completely". Zob. w: Webster's New Collegiate Dictionary, s. 902.

${ }^{35}$ Por. W. E. Kaufman, The Concept of Transcendence, s. 8. 
za pomocą którego boskość transcenduje to, co mechaniczne ${ }^{36}$. Natura pojmowana jako maszyna jest całością, której pojedyncze funkcje działają automatycznie przez jej części. Natomiast natura rozumiana jako organizm - jak ma to miejsce w przypadku Kaplana - jest całością z częściami tak zintegrowanymi, że ich wzajemne odniesienie jest kierowane przez ich odniesienie do całości. Możemy powiedzieć, że proces samo-transcendencji w teorii Kaplana jest indywidualnym pędem do totalności lub samo-integracji z wszechświatem. Ostatecznym przedmiotem transcendencji jest Bóg jako proces kosmiczny, który tworzy naturę jako zintegrowaną całość. Relacja między tym, co trans-naturalne (transcendentny Bóg), a człowiekiem polega na boskiej funkcji w człowieku, którą należy rozumieć ,jako wymuszony pęd do samo-integracji lub indywidualizacji $\mathrm{w}$ sensie utożsamienia lub zadomowienia w świecie" ${ }^{\prime 37}$.

Kaplan przedstawia swoje rozumienie transnaturalizmu w następujących słowach: „Transnaturalizm jest takim rozwinięciem naturalizmu, który bierze pod uwagę sporo z tego, czym są w stanie zajmować się nauki mechanistyczne, materialistyczne lub pozytywistyczne. Transnaturalizm sięga w dziedzinę, gdzie rozum, osobowość, cel, ideały, wartości i znaczenia występują. Uwzględnia to, co dobre i to, co prawdziwe. Czy ma to swoją własną logikę, jest problematyczne. Z pewnością jednak ma swój język, język porównania, metafory i poezji. Jest to język symbolu, mitu i dramatu. W świecie dyskursu wiara w Boga oznacza wiarę w życie i w człowieka, która jest w stanie transcendować potencjalności zła tkwiące w zwierzęcej dziedziczności, w społecznym dziedzictwie, w uwarunkowaniach środowiska. Transnaturalistyczna religia dostrzega Boga w dopełnieniu ludzkiej natury, a nie w zawieszeniu porządku natury. Jego zadaniem nie jest wspomaganie człowieka $w$ pokonaniu niebezpieczeństw natury, lecz uzdolnienie go do tego, aby poddał kontroli to, co nieludzkie w stosunku do innych istot ludzkich"38.

${ }^{36}$ Por. tamże, s. 9.

${ }^{37}$ M. M. Kaplan, The Religion of Ethical, s. 79.

38 "Transnaturalism is that extension of naturalism which takes into account much that mechnistic or materialistic or positivist science is incapable of dealing with. Transnaturalism reaches out into the domain where mind, personality, purpose, ideals, values and meanings dwell. It treats of the good and the true. Whether or not it has a distinct logic of its own is problematic. But it certainly has a language of its own, the language of simile, metaphor and poetry. That is the language of symbol, myth and drama. In that universe of discourse, belief in God spells trust in life and in man, as capable of transcending the potentialities for evil that inhere in his animal heredity, in 
Z definicji transnaturalizmu Kaplana wynika jednocześnie, że naturalizm klasyczny również nie jest adekwatnym sposobem rozumienia rzeczywistości, albowiem nie jest $\mathrm{w}$ stanie zbadać oraz wyjaśnić fenomenu umysłu, osobowości, ideału, celu, wartości i znaczenia. Kaplan poszukuje transcendentnego źródła tych fenomenów, ponieważ stoi na stanowisku, że czysto naturalistyczna konceptualna struktura nie może uprawomocnić moralnych dążeń człowieka. Potrzeba transcendentnej podstawy dla wartości ludzkich, której człowiek nie może odnaleźć $\mathrm{w}$ naturze rozumianej immanentnie, wyłania koncepcję Boga jako siły, która prowadzi do zbawienia ${ }^{39}$. „Od przyjęcia ram wartości ludzkich, których znaczenie wyprowadza się z dążenia człowieka do zbawienia, doskonałości lub samo-transcendencji, jest tylko jeden logiczny krok do wiary w Boga jako siły, która skłania człowieka do obrania właściwego kierunku, i która uzdalnia go przynajmniej do podążania w perspektywie swego przeznaczenia. Doświadczamy rzeczywistości Boga w tym, co daje nam poczucie wartościowości życia pomimo zła, które napotykamy w życiu oraz we wszystkim tym, co skłania nas do podążania za naszym poczuciem odpowiedzialności moralnej bez względu na konsekwencje $^{\prime \prime 40}$. Kaplan świadomy niemocy wyprowadzenia normatywności z faktycznych stwierdzeń i rozczarowany mechanistycznymi implikacjami czystego naturalizmu nie jest $\mathrm{w}$ stanie osadzić dobrego życia człowieka na naturze. Dlatego wypracowuje stanowisko pośrednie między naturalizmem a supernaturalizmem, które określa mianem transnaturalizmu. Zgodnie z logiką transnaturalizmu, nie natura człowieka, lecz natura Boga, rozumiana jako proces twórczy zamanifestowany w organiczności i wzajemności, jest źródłem wartości moralnych.

his social heritage, and in the conditions of his environment. Transnaturalist religion beholds God in the fulfillment of human nature and not in the suspension of the natural order. Its function is not to help man overcome the hazards of nature, but to enable him to bring under control his inhumanity to his fellow-man" - M. M. Kaplan, Judaism without Supernaturalism, New York 1958, s. 10.

${ }^{39}$ Por. W. E. Kaufman, The Transnatural Theology, s. 46.

40 "From the adoption of the frame of human values, which derive their significance from man's striving for salvation, perfection or self-transcendence, it is but one logical step to the belief in God as the Power that impels man to pursue that course and that enables him at least to come within sight of its destination. We experience the reality of God in whatever gives us a sense of life's worthwhileness, despite the evils that mar life, and in whatever drives us to follow our sense of moral responsibility, regardless of consequences". M. M. Kaplan, Judaism without, s. 25. 
Rekonstrukcjonistyczny transnaturalizm „wykracza poza obszar rozumu, osobowości, celowości, ideałów, wartości i znaczeń"41. Jak utrzymują krytycy myśli Kaplana ${ }^{42}$, twórca tej teologii był przekonany, że istnieje faktyczny ontologiczny wymiar rzeczywistości, który transcenduje człowieka i generuje jego najwyższe wartości ${ }^{43}$. Wydaje się, że jest to osąd wielce prawdopodobny z kilku powodów. Po pierwsze, Kaplan kategorycznie odrzuca mechanistyczne, materialistyczne lub pozytywistyczne nauki. Nie zgadza się z poglądem, że umysł ludzki jest po prostu epifenomenem, który wyłonił się przypadkowo w drodze ewolucji. Kaplan, kierując się teorią stopniowej ewolucji, twierdzi, że umysł i wartości rozwijają się ustawicznie i nieprzypadkowo, ponieważ są istotne w całej strukturze wszechświata. Po drugie, Kaplan twierdzi, że wartości, chociaż niewidzialne i niedotykalne, są tak samo prawdziwe jak widzialne i uchwytne zmysłowo fakty lub rzeczywistości. Po trzecie, Kaplan stoi na stanowisku, że istnieje ontologiczna rzeczywistość większa od umysłu ludzkiego, która generuje umysł człowieka ${ }^{44}$. Po czwarte, Kaplan utrzymuje, że istnieje realnie poziom egzystencji, który jest większy i wyższy od człowieka, i który stanowi źródło moralnego zmagania się człowieka ${ }^{45}$.

Dla Kaplana teoria religii zaczyna się od założenia, że jest ona wyrazem powszechnej woli życia. „Innymi słowy, dla istot ludzkich

${ }^{41}$ M. M. Kaplan, tamże, s. 10.

${ }^{42}$ Zob. W. E. Kaufman, The Transnatural Theology, s. 51

${ }^{43}$ Kaplan próbując wyjść poza ograniczenia naturalizmu twierdzi, że istnieje jakiś ontologiczny wymiar rzeczywistości, jakiś poziom, jakaś dziedzina, która jest źródłem wartości. Tym samym popada w platońską metaforę, kiedy wyraźnie mówi o tym, że „umysł, osobowość, ideały, wartości i znaczenia... mieszczą się". Zob. M. M. Kaplan, Judaism without, s. 10.

${ }^{44}$ "There is nothing in mind which requires us to stop and say, this is the highest empirical quality which which time can produce from now throughout the infinite time to come. It is only the highest empirical quality which we who are minds happen to know" (Nie ma niczego w umyśle, co nie pozwoliłoby nam powiedzieć, że jest wyższa empiryczna jakość, którą czas może wyłonić od teraz przez czas nieskończony, który nastąpi. Jest to jedyna najwyższa jakość empiryczna, którą nam jako umysłom zdarza się poznać). M. M. Kaplan, The Religion of Ethical, s. 111. Faktycznie jest to teoria, którą Kaplan przejął od Samuela Alexandra (1859-1938), australijskiego filozofa, który swoje metafizyczne tezy opierał na życiowych aspektach rzeczywistości i wyjaśniał je w najbardziej prosty i najbardziej ekonomiczny sposób. Jego najpopularniejsze dzieło to: Space, Time and Deity, Jerusalem 1929.

45 "Nature's God directs the affairs of men to effect the metamorphosis of the human species" (Natura Boga kieruje sprawami ludzkimi, aby osiągnąć metamorfozę gatunku ludzkiego). M. M. Kaplan, The Religion of Ethical, s. 113. 
wola życia staje się wolą zbawienia, osiągnięcia dobrego życia"46. Religia $\mathrm{w}$ rozumieniu rekonstrukcjonistów jest częścią przystosowania się człowieka do świata. Kiedy mówią, że „człowiek poszukuje dobra”, znaczy to dla nich, że „człowiek poszukuje samo-spełnienia”. Judaizm jest więc wyrazem woli do samo-spełnienia czyli zbawienia, i jako taki jest odzwierciedleniem powszechnego fenomenu trwania człowieka. Jak „,człowiek staje się świadomy siebie jako osoby angażując się w zmaganie $\mathrm{z}$ niebezpieczeństwami i trudnościami, tak też staje się świadomy wsparcia ze strony Siły lub sił, aby pokonać przeszkody"47. Dążenie człowieka do zbawienia prowadzi do rozpoznania sił, które podtrzymują go, umacniają i wspierają na tej drodze ${ }^{48}$.

W każdej religii koncepcja zbawienia jest nierozerwalnie związania z koncepcją Boga, która jest pierwszą, zasadniczą i warunkującą inne pojęcia $\mathrm{w}$ danej religii. $\mathrm{W}$ rekonstrukcjonizmie jest zupełnie odwrotnie. „Aby religia żydowska była w stanie wyjść naprzeciw potrzebom współczesnych mężczyzn i kobiet, musimy - jak przekonuje Kaplan - osiągnąć możliwą do zaakceptowania koncepcję zbawienia, jako warunek do zaakceptowania koncepcji Boga"49. Z powyższej wypowiedzi wynika, że koncepcja Boga jest wtórna do koncepcji zbawienia. Bóg jest potraktowany przez Kaplana jako dopełnienie teorii soteriologicznej, jako instrument, którego zadaniem ma być pomaganie człowiekowi i całej naturze spełnić siebie.

Podejście Kaplana opiera się na sądzie, że „przez przesunięcie orientacji z koncepcji Boga, gdzie cel był umieszczony poza doświadczeniem ludzkim"50, na ideę człowieka, gdzie zbawienie jako cel życia pozostaje w granicach tego świata, można dokonać właściwej rekonstrukcji

46 "In other words, for human beings the will to live becomes the will to salvation, to the achievment of the good life". M. M. Kaplan, The Future, s. 173.

47 "man becomes aware of himself as a person engaged in in struggle against dangers and difficulties, he also becomes cognizant of help of a Power or powers to conquer obstacles". Tamże, s. 171.

${ }^{48}$ Por. H. C. Weisberg, Mordecai M. Kaplan's Theory of Religion, w: I. Eisenstein, E. Kohn (red.), Mordecai M. Kaplan: An Evaluation, New York 1952 s. 174.

49 "To enable Jewish religion to met the needs of modern men and women, we must achieve an acceptable conception of salvation, as a prerequisite to an acceptable conception of God". M. M. Kaplan, The Future, s. 203.

50 "by shifting the oreintation from the God-concept, a point intended to be outside human experience". M. M. Kaplan, The Art of Being Human, w: nieopublikowany manuskrypt znajduje się w archiwum Reconstructionist Rabbinical College (1299 Church Road, Wyncote, Pa 1995). 
idei zbawienia w judaizmie ${ }^{51}$. Tradycyjny teocentryzm został wyraźnie zastąpiony antropocentryzmem w odniesieniu do idei zbawienia. Istota ludzka jako „animal symbolicum” obrazu Boga wkracza w świat możliwości, powinności i wartości. Życie religijne wyraża się niejako w zwracaniu się ku tym elementom rzeczywistości, które ulepszą egzystencję człowieka i w poszukiwaniu sił, które umożliwią mu pokonanie zła. Rekonstrukcjonistyczna religia nie polega na wyznaniu wiary, lecz na ustawicznym procesie doskonalenia siebie i społeczeństwa, na nieprzerwanym zmaganiu się z przeciwnościami, na wznoszeniu się na wyższy poziom egzystencji, na doskonaleniu swojego człowieczeństwa, na trosce i czci tego, co w człowieku i w świecie stanowi element boski ${ }^{52}$. Mamy tu do czynienia nie tyle z próbą uczłowieczenia (antropomorfizacji) Boga, którą Kaplan programowo odrzucał, co raczej z ubóstwieniem (deifikacją) człowieka i całej natury.

Rewolucyjny charakter rekonstrukcjonistycznego podejścia soteriologicznego nie leży w zastosowaniu naturalizmu, lecz w humanistycznej interpretacji osobowego zbawienia. Poszukiwanie boskości w tym i w takim świecie pociąga za sobą odkrycie w sobie tego, co boskie, a co prowadzi do pełni człowieczeństwa. Celem religii, celem życia jest człowiek, a nie jakkolwiek pojmowany Bóg. Tak wyrażony antropocentryzm traktuje boskość instrumentalnie, jako narzędzie do osiągnięcia zbawienia, czyli samo-spełnienia człowieka na tym świecie. Człowiek z głębi siebie wydobywa boskość. Troska o zbawienie sprowadza się do świadomej realizacji w sobie i w innych wszelkich humanizujących możliwości. Ich aktualizacja stanowi osobiste i społeczne zbawienie. Soteriologia rekonstrukcjonistyczna jest faktycznie badaniem natury i ukazywaniem metody osiągania celu na tym świecie, ponieważ - z założenia rekonstrukcjonistycznego - nie ma innej natury i innego świata.

Wiara Kaplana opiera się na dwóch podstawowych i niezbywalnych prawdach dotyczących natury człowieka: „woli życia” i „woli, aby żyć w pełni" ${ }^{\prime 23}$. Ostatecznie tak rozumiana wiara zmierza do samo-realizacji, która dokonuje się poprzez rozwój twórczej osobowości jaźni na każdym poziomie egzystencji ${ }^{54}$. Na poziomie żywotności jaźń wyraża się

${ }^{51}$ Por. H. M. Schulweis, A Critical Assessment of Kaplan's Ideas of Salvation, w: E. S. Goldsmith, M. Scult, R. M. Seltzer (red.), The American Judaism of Mordecai M. Kaplan, New York and London 1990, s. 259.

${ }^{52}$ Por. tamże.

${ }^{53}$ Zob. M. M. Kaplan, The Future, s. 172.

${ }^{54} \mathrm{Na}$ temat poziomów egzystencji i przynależnych im potrzeb w myśli Kaplana 
w organicznych i biogenicznych potrzebach (głód lub seks) oraz w potrzebach socjogenicznych (potrzeba przynależności do grupy i zajmowania odpowiedniej $\mathrm{w}$ niej pozycji ${ }^{55}$. Na poziomie rozumu i inteligencji jaźń funkcjonuje jako pośrednik w konflikcie pierwszeństwa i ważności potrzeb, aby osiągnąć harmonię poprzez nabywane doświadczenia indywidualne i zbiorowe, które rozum rejestruje. Inteligencja człowieka jest jednocześnie decydującym narzędziem rozpoznawania możliwości jaźni i jej rozwoju ${ }^{56}$. Na poziomie moralnym jaźń jest „portem wartości” i „królestwem celów”. Na tym poziomie jaźń dostarcza emocjonalnego ładunku, który przekształca zobowiązania etyczne i intelektualne w czyn. Człowiek dzięki pozytywnym emocjom z odwagą i całkowitą determinacją jest w stanie odważnie realizować wartości, które są istotne dla jednostki i grupy ${ }^{57}$. Uwzględniając powyższe należy soteriologię rekonstrukcjonistyczną zdefiniować jako „naukę normatywną o życiu ludzkim we wszystkich jego aspektach z punktu widzenia weryfikowalnego doświadczenia". ${ }^{58} \mathrm{~W}$ rekonstrukcjonizmie religijny człowiek jest postrzegany jako artysta, który pobudzony przez imperatyw soteriologiczny przekształca swoją jaźń, nadając jej nową, lepszą formę.

Pragnienie osiągnięcia pełni życia lub samo-realizacji jest w rekonstrukcjonizmie uznawane za powszechne i wrodzone (naturalne) pragnienie każdego człowieka. Obejmuje ono wiele poziomów aktywności jaźni, które domagają się scalenia i zapośredniczenia. Samoświadomość i rozumność są konieczne przynajmniej z dwóch powodów: aby w najlepszy i najpewniejszy sposób zaspokoić pragnienia, i aby zintegrować lub zrównoważyć siłę impulsów poszczególnych pragnień w celu osiągnięcia zdrowej dla człowieka harmonii. W takiej koncepcji pułap zbawienia jest określony przez stopień wrażliwości i samo-świadomości konkretnego

zob. H. M. Schulweis, A Critical Assessment of Kaplan's Ideas of Salvation, w: E. S. Goldsmith, M. Scult, R. M. Seltzer (red.), The American Judaism of Mordecai M. Kaplan, New York-London 1990, s. 259-260.

${ }^{55}$ Kaplan twierdzi, że tzw. "filozofie ascetyczne” negują tego rodzaju potrzeby lub je lekceważą, co z soteriologicznego punktu widzenia jest szkodliwe dla zdrowego rozwoju człowieka i samego zbawienia.

${ }^{56} \mathrm{Z}$ tego powodu nie może jaźń lekceważyć zdobyczy nauki i akceptować bezkrytycznie autorytetu przeszłości.

${ }^{57}$ Ta emocjonalna formacja ma miejsce podczas rytualnych celebracji i na modlitwie. Wówczas dziedzina celów jest rozpoznana, uświadomiona i wyartykułowana.

58 "...normative science of human life in all its aspects, from the standpoint of verifiable experience". M. M. Kaplan, The Art of Being Human, s. 33. 
człowieka $^{59}$. Znaczy to również, że poczucie osiągnięcia zbawienia jest subiektywne, uwarunkowane i indywidualne. Najlepiej wyraża to znana skądinąd teza: „każdemu według potrzeb”. Człowiek będzie szczęśliwy, a więc zbawiony, jeśli zostaną zaspokojone jego wszystkie potrzeby i potrzeby innych członków wspólnoty, do której jednostka należy. Warunkiem osiągnięcia takiego stanu jest posiadanie przez człowieka odpowiedniej wrażliwości i samo-świadomości, które to cechy zostały nazwane przez Kaplana „wymiarem artystycznym”.

Kaplan traktuje powszechną wolę życia i ludzką wolę samo-realizacji jednakowo. Obie wole mają służyć za podwalinę normatywności rodzaju ludzkiego i to niezależnie od różnic, jakie zachodzą między konkretnymi społecznościami. Ściśle określone społeczności dostarczają jednostce i grupie norm postępowania, których skuteczność jest oceniana w perspektywie globalności wszechświata. Soteriologiczna propozycja Kaplana stanowi hipotetyczną metodę osiągania zbawienia. Taka hipoteza domaga się jednak pewnej metafizycznej struktury, w której filarami są trzy założenia ${ }^{60}$. Po pierwsze, w człowieku istnieje jakaś uniwersalna, biologiczna, psychologiczna i społeczna potrzeba zbawienia. Po drugie, świat jest tak ukonstytuowany soteriologicznie, aby umożliwić zbawienie ludzkości. Po trzecie, zintegrowane zaspokajanie potrzeb ludzkich jest wartością samą w sobie.

$W$ rekonstrukcjonizmie idea zbawienia jest umieszczona na tym samym poziomie, co idea życia biologicznego, psychicznego i społecznego. Natura jaźni odgrywa tutaj rolę podstawowej kategorii soteriologicznej, ponieważ istota wartości ujawnia się działaniu, którego celem ma być aktualizowanie naturalnych tendencji jaźni. To właśnie jaźń doświadcza pragnień i ona dąży do ich zaspokojenia. W niej też zawarte są materialne, formalne, celowe i sprawcze przyczyny bycia ludzkiego. Tak rozumiane zbawienie ma wymiar tylko immanentny i tylko humanistyczny. Zbawić się to tyle, co osiągnąć maksimum zdrowia fizycznego i psychicznego, siły twórczej oraz moralności w życiu społecznym. Idea zbawienia tego świata i na tym świecie nie eliminuje rzeczywistości zła. „Królestwo Boże” na tym świecie nie jest w koncepcji Kaplana rzeczywistością idealną, lecz parafrazując Leibniza - światem najlepszym z możliwych. Zbawić świat to uczynić go najlepszym z możliwych. Taki obraz zbawienia potwierdza jedynie tezę, że dobro jest rzeczywiste, a nie, że rzeczywistość jest dobra.

\footnotetext{
${ }^{59}$ Por. H. M. Schulweis, A Critical Assessment, s. 262.

${ }^{60}$ Por. tamże, s. 365.
} 
Kaplan podkreśla, że ,jjak dalece wiara w Boga wpływa na życie osoby lub życie grupy, tak musi mieć konsekwencje w dziedzinie efektywności” $^{\prime \prime 1}$. Z tego powodu rekonstrukcjonistyczną koncepcję zbawienia można próbować zrozumieć jedynie w oparciu o kryterium pragmatyczne.

Na czym konkretnie ma polegać zbawienie w programie rekonstrucjonistów? Poniższe stwierdzenie można uznać za próbę odpowiedzi na to pytanie. „W obecnym stadium rozwoju ludzkiego zbawienie wymagałoby życia zgodnego z najwyższą prawdą, którą doświadczenie odsłania w stopniu wystarczającym"62. Wśród tych prawd Kaplan wymienia ${ }^{63}$ : 1) Zbawienie jednostki polega na zaspokojeniu trzech głównych potrzeb: fizycznych (obejmują one te potrzeby, które decydują o zdrowiu), emocjonalnych (wśród nich na pierwszym miejscu jest miłość, ponieważ każdy człowiek musi czuć, że jest w bliskiej relacji z innymi istotami ludzkimi, dla których jest ważny i które są ważne dla niego), twórczych (istota ludzka potrzebuje sposobności do wyrażania siebie w niepowtarzalny i osobisty sposób); 2) Zbawienie rodzaju ludzkiego ma oznaczać traktowanie innych ludzi (bez względu na rasę, narodowość, wiarę, płeć) jako cele same $\mathrm{w}$ sobie, a nie jako środki do zaspokajania pragnień innych ludzi. Ludzie jako cele same w sobie są przeznaczeni do realizacji swoich twórczych możliwości; 3) Celem społeczeństwa jest umożliwienie jednostce osiągnięcia zbawienia przez tworzenie społecznych struktur (wspólnoty ludzi, intelektualnych dyskusji, organizacji inicjatyw na rzecz innych, rytualnych celebracji). Zdaniem Kaplana, rzeczywistość boska towarzyszy człowiekowi tak długo i w takim stopniu, jak jest on pobudzany przez nieodparty pęd ku pełni życia. Ten pęd jest $\mathrm{w}$ rekonstrukcjonizmie rozumiany jako przymus wewnętrzny, aby poszukiwać najwyższego dobra, którego osiągnięcie dostarczy istocie ludzkiej wartości i znaczenia. „To jest sposób w jaki odczuwamy obecność Boga"64.

Osiągnięcie przez człowieka szczęścia czyli samo-spełnienia jest związane i z aktywnością ludzką i z działaniem boskiej Siły. Człowiek jest stworzony $\mathrm{z}$ tych samych elementów, z których zbudowany jest

61 "...insofar as the belief in God makes a difference in a person's or in the life of group, it must have consequences in the domain of effectivness" - M. M. Kaplan, Art of Being Human, s. 75.

62 „But at the present stage of human development, salvation would involve iving according to the highest truth that experience has thus far revealed". M. M. Kaplan, The Future, s. 206.

${ }^{63}$ Zob. tamże, s. 207.

${ }^{64}$ „That is the way we feel the presence of God". Tamże. 
świat. Sam nie jest odpowiedzialny za swój wzrost, za kształtowanie się, za funkcjonowanie swoich organów, za skład chemiczny swojej krwi, za wszystko, co w nim i wokół niego warunkuje życie ludzkie. W rekonstrukcjonizmie możemy mówić, że człowiek jest współodpowiedzialny, współtworzący, współkształtujący i współzależny. Korelatem dla człowieka jest zawsze Siła boska, która jest w człowieku i w całej naturze. Ludzka jaźń jest znakiem tej Siły, która stwarza byt ludzki jako istotę odpowiedzialną za organizowanie i kierowanie wszystkimi aktywnościami człowieka. "Jego życie nigdy nie jest w całości jego, ani też jego zbawienie nie jest jego własnym osiągnięciem. Nie na sobie, lecz na nie swojej Sile, która prowadzi do zbawienia, musi polegać, aby uczynić życie wartym życia" 65 . Dlatego Kaplan tak mocno i ustawicznie podkreśla, że dla współczesnego Żyda wiara w Boga powinna znaczyć wiarę w Siłę, która prowadzi do zbawienia.

Świadomy udział w aktywności Boga jako Siły wiąże się w sposób konieczny z twórczością i odpowiedzialnością człowieka. Wydaje się jednak, że w rekonstrukcjonizmie człowiek nie jest odpowiedzialny przed Bogiem jako nieosobową Siłą, lecz przed sobą i ludzkością jako taką. Motywem moralnego postępowania człowieka nie jest chęć osiągnięcia przyszłego życia jako nagrody za dobre życie tu na ziemi. W rekonstrukcjonizmie chodzi o zbawienie na tej ziemi, dlatego, jeśli człowiek chce osiągnąć samo-spełnienie, musi postępować moralnie. Czyni to niejako dla siebie i dla ludzkości, nie dla Boga lub ze względu na Boga. „Wiara w Boga jest wiarą w możliwości takich osiągnięć, bez których nieuchronnie toniemy $w$ moralnym defetyzmie. To jest powód, dlaczego wiara religijna, w sensie wiary w Siłę, która prowadzi do zbawienia, jest niezbywalna dla współczesnego człowieka w stopniu nie mniejszym niż była dla jego przodków, jako powtórne respektowanie życia etycznego" ${ }^{\prime \prime 6}$.

We wszystkich istotach żyjących wola życia wyraża się w różnych pragnieniach i popędach. Człowiek jednak posiada mentalne możliwości, które umożliwiają mu to, że jest świadomy celów i środków, całości i czę-

65 „His life is never wholly his own, nor his salvation his own achievement. Not on himself, but on a Power not himself that makes for salvation, he must rely to make life worth living". Tamże.

${ }^{66}$ "Faith in God is faith in possibility of such achievements, without which we inevitably sink into moral defeatism. That is why religious belief, in the sense of faith in the Power that makes for salvation, is indispensable to modern man no less than it was to his forefathers, as reenforcement for ethical living". Tamże, s. 202. 
ści, siebie i nie siebie. Ta zdolność doprowadziła człowieka do myślenia w pojęciach ogólnych i abstrakcyjnych. Przez to ludzie stali się świadomi sami siebie jako osób, które są uwikłane w zmaganie z przeciwnościami życia oraz świadomi Siły lub sił, które wspomagają ludzkość w tym wysiłku. Ta świadomość znalazła swój wyraz w ideach. To, co najbardziej wyróżnia istotę ludzką od innych istot, zostało określone jako „dusza”, a wyróżniona Siła lub siły, które towarzyszą człowiekowi w osiągnięciu ostatecznego celu, zostały nazwane „Bogiem”. Bóg i dusza są dla siebie korelatami. Wzajemna relacja między tymi dwoma ideami wyjaśnia jednocześnie, dlaczego wraz ze zmianami koncepcji osoby ludzkiej następowała w sposób konieczny zmiana koncepcji Boga ${ }^{67}$. Z czasem umiejętność człowieka do generalizowania doprowadziła ludzkość do pojmowania Boga jako Bytu uniwersalnego. „Równocześnie z przejściem od pojęcia bogów do pojęcia Boga, i od specyficznych, niezależnych impulsów do całości jako woli życia, nastąpił pierwszy krok od przypadkowego dążenia do świadomego ukierunkowania wysiłków, aby zaspokoić ową wolę. Człowiek stał się stopniowo świadomy swojego celu i posiadania wyboru między bardziej lub mniej pożądanymi celami oraz między dobrymi i złymi metodami jego osiągania"68.

Kaplan podkreśla, że fundamenty wiary nie są wynikiem spekulacji rozumu, lecz bezpośredniego pędu człowieka, aby osiągnąć maksymalne życie, które zostało nazwane zbawieniem lub samo-spełnieniem. To przejście od dążenia do zbawienia do istnienia Boga zostało nazwane przez rekonstrukcjonistów przejściem soteriologicznym. Biologiczna wola życia zakłada istnienie warunków, które są sprzyjające życiu. Ludzka wola życia pełnego i wola osiągnięcia przeznaczenia także domaga się warunków, które umożliwiają pełnię życia czyli zbawienie. „Uznanie za prawdę, że takie warunki istnieją, jest podstawą religijnej koncepcji Boga. Religijna koncepcja Boga nie jest więc konsekwencją pierwszej przyczyny lub zasady porządku wszechświata, lecz koncepcją Siły usposobiającej

${ }^{67}$ Kaplan ukazuje ową korelację w oparciu o następujący przykład: jeśli myślimy o duszy jako niezależnej od ciała, wówczas pojmujemy Boga jako byt niezależny od rzeczywistości materialnej. Tamże.

68 ",Simultaneously with progress from the notion of Gods to that of God, and from specific independent urges to the whole of the will to live there has been an advance from haphazard attempts to consciously directed effort to satisfy that will. Man becomes progressively aware of his goal, and of having to choose between more and less desirable objectives and between right and wrong methods of attainment". Tamże, s. 172. 
człowieka do osiągnięcia ostatecznego dobra ludzkiego, zbawienia lub samo-spełnienia"69.

Rekonstrukcjonistycznie pojmowana wiara zakłada, że życie jednostki ani nawet grupy nie reprezentuje w żaden sposób swojej totalności. „Rzeczywiście to, co oglądamy, jest po prostu wzburzoną powierzchnią bezgranicznej głębi Bytu, skąd wyłoni się z czasem to potencjalne dobro, które przemieni oblicze ludzkiej egzystencji. Oparcie życia na takiej ufności ma być aktywizowaniem potencjalności dobra. Istnienie takiego potencjalnego dobra jest tym, co człowiek potwierdza nie tylko w myśli, lecz w woli, w każdym czasie, kiedy polega na superludzkiej Sile, aby spełnić swój ludzki cel. Na tym buduje swoją wiarę, że jego ideały nie są ułudą, lecz boskim światłem oświetlającym drogę do spełnienia"70.

Odkrycie przez człowieka elementów w naturze, które warunkują i wspomagają zbawienie rozumiane jako samo-spełnienie, nie oznacza w rekonstrukcjonizmie odrzucenia wiary w Boga. Jak czytamy: „religia nawet w swoim prymitywnym stadium nigdy nie zwalniała człowieka z potrzeby realizowania własnych fizycznych i psychicznych pragnień, jeśli chciał on osiągnąć to, co uznawał za ostateczne dobro. To znaczy, że człowiek ciągle występował jako współpracownik Boga w procesie zbawienia"71. Jednocześnie Kaplan przestrzega, że żadna ludzka moc kontrolowania warunków w naturze, które umożliwiają zbawienie, nie może przesłonić człowiekowi prawdy, że efektywność ich działania zależy od sił i tendencji, które zawarte są w kosmosie. Żaden określony przez jednostkę ludzką lub społeczność plan zbawienia nie może zatracić perspektywy całościowej. To kosmos jako całość jest tak ukonstytuowany, aby umożliwić i doprowadzić człowieka do zbawienia. Wynika z tego,

${ }^{69}$ "The taking for granted that such conditions exist is the basis of the religious conception of God. The religion conception of God is thus not the conception of a first cause, or of an oredring principle in the universe, but of a Power predisposing man to his ultimate human good, salvation or self-fulfillment". Tamże.

${ }^{70}$ "Indeed, what we behold is merely the agitated surface of the boundless deep of Being, whence will in time emerge that potential good which will transform the face of human existence. The base one's life on such confidence is to activate that potential good. The existence of that potential good is what man affirms not merely in thought, but in will, every time he looks to a superhuman Power for the fulfillment of his human aims. On this he builds his faith that his ideals are not will-o'-the-wisps, but a divine light illuminating the path to fulfillment". Tamże, s. 173.

${ }^{71}$ "religion even in its primitive stage never exemted man from the need of exerting his own mental or physical effort, if he wanted to achieve what he regarded as his ultimate good". Tamże. 
że zbawienie nie zależy tylko od człowieka ani też tylko od Siły lub sił tkwiących w naturze wszechświata. Zbawienie jest współzależne od Boga i człowieka. „Widzieć kosmos w taki sposób, znaczy wierzyć w Boga”72.

Konsekwentnie Kaplan zmienił koncepcję duszy ${ }^{73}$ lub osobowości. Odrzuca wszelkie poglądy, gdzie rzeczywistość duszy jest związana z identyfikowaniem jej jako wyróżniona jaźń, która jest oddzielona od ciała. Duszę pojmuje jako indywidualny proces, przez który osoba ludzka osiąga pełnię życia lub zbawienie. W ten sposób rekonstrukcjoniści utrzymują jej realność bez konieczności myślenia o niej jako o substancjalnym bycie. „Dusza-proces jest także superfaktyczna, superdoświadczalna i trans-naturalna"74. W teologii trans-naturalnej ludzka jaźń nie jest monadą, lecz „duadą", która składa się z części potencjalnych i części zaktualizowanych. Zaktualizowana część jest zawarta w ciele wraz z potrzebami biologicznymi i zespołem nawyków, postaw i ideałów ograniczających te potrzeby. Część potencjalna wyraża się w działaniu tych uniwersalnych sił w środowisku, z którymi jednostka ludzka musi współpracować, aby osiągnąć swoją pełnię. Ta duchowa część aktualizuje się jako prawda, kiedy ludzki umysł wydobywa wiedzę na temat rzeczywistości. Aktualizuje się także jako dobro, kiedy ludzka wola pobudza człowieka do miłości. „Kiedykolwiek człowiek rozumuje lub radzi się swojego sumienia, bierze udział w dialogu. Dzieje się tak również wtedy, kiedy się modli. Wtedy ta jego część, która stanowi w nim zaktualizowany element, kieruje się do tej części, która jest potencjalna. Wtedy cała osobowość jest połączona. Kiedy cała osobowość jest scalona, zawiera koniecznie coś boskiego, co ją transcenduje" $\mathrm{e}^{\prime 75}$. Modlitwa jest scalaniem jaźni, motywowaniem siebie, nabieraniem przekonania, odkrywaniem w sobie siły do działania, własnym spełnieniem. Poddana rekonstrukcjonistycznej transwaluacji nie jest na pewno zwracaniem się do Boga, aby uczynił coś dla człowieka lub za człowieka.

72 "To view the cosmos in this way is to believe in God". Tamże, s. 182.

${ }^{73} \mathrm{~W}$ starożytności dusza była najczęściej rozumiana jako zasada życia (Arystoteles). W filozofii nowożytnej od czasu Kartezjusza jest uznawana za zasadę myślenia.

${ }^{74}$ "The soul-process, too, is superfactual, superexperiental and trans-natural". M. M. Kaplan, The Future, s. 183.

75 ,Whenever man reasons or consults his conscience, he is engaged in dialogue. So, also, when he prays. Then that part of him which is the actualized element in him addresses itself to that part which is potential. It is then that one's entire personality is impicated. When one's personality is entire, it necessarily includes something of the divine which transcends it". Tamże, s. 184-185. 
W myśli Kaplana rewaluacja suwerenności Boga ma swoje odniesienie do odpowiedzialności indywidualnej w ramach cywilizacji żydowskiej i ludzkości w ogóle. Człowiek jest odpowiedzialny za rozwijanie społeczności, do której przynależy: rodziny, narodu, ludzkości. Każda istota ludzka jest zarazem i dla siebie, i dla innych. Zachowując swoją wolnośc i prawo do samo-realizacji, poszczególny członek społeczności musi wyjść poza siebie i włączyć się w realizację zbiorowego celu, jakim jest spełnienie się społeczności przez ustanowienie idealnego porządku. Do takiej postawy pobudza człowieka Siła, która tkwi w naturze ludzkiej. Podporządkowanie się tej Sile jest budowaniem Królestwa Bożego na tej ziemi. Dlatego jednostka ludzka patrzy nie w niebo, lecz na ten świat jako swój świat, w którym może spełnić siebie i być elementem spełnienia się innych jednostek społeczności. To jest też powód, dlaczego w rekonstrukcjonizmie każdy indywidualny człowiek jest niepowtarzalny i niezastąpiony. "Jeśli Królestwo Boże jest ustanowione na ziemi, musi być ustanowione przez jednostki"76. Odpowiedzialność poszczególnego człowieka za to, jak używa swoich wrodzonych zdolności w ustanawianiu Królestwa Bożego, ma swoje podstawy w religijnej idei duszy, którą Kaplan rozumie nie jako wyróżnioną i samoistną substancję, lecz jako „boską iskrę”.

Można powiedzieć, że w rekonstrukcjonizmie dusza ludzka jest częścią rzeczywistości boskiej, częścią Boga jako Siły. „Dla pewności, nasze pojęcie duszy nie może być takie, jakie mieli nasi ojcowie. Trzeba także dokonać zmiany podobnej do tej, jaka miała miejsce w odniesieniu do pojęcia Boga. Nie możemy dłużej patrzeć na duszę jako na coś niewidzialnego we wnętrzu człowieka, co zamieszkuje i animuje ciało. Dusza nie jest niczym innym niż istotą ludzką jako osoba lub jaźń"77. Bóg jako Siła działa w człowieku i przez człowieka, ponieważ dusza ludzka jest tu rozumiana jako część boskiej Siły. „Bóg jako Siła, która prowadzi do odnowy społecznej, może działać tylko przez dusze ludzi. Dlatego Jego suwerenność zależy od nich. Jak suwerenność narodu tkwi w obywatelach i ich relacjach do państwa, tak suwerenność Boga tkwi w duszach ludzi i ich relacji do społeczności"78.

${ }^{76}$ "If God's Kingdom is established on earth, it must be established by individuals". Tamże, s. 113.

77 "It must undergo a change similar to the change in our conception of God. We can no longer look upon the soul as a sort of invisible inner man that inhabits and animates the human body. The soul is nothing other than the human being as a person or self". Tamże.

${ }^{78}$ "God as the Power that makes for social regeneration can act only through the 
Kaplan mocno przeciwstawia się dualizmowi ciała i duszy, który był obecny również $\mathrm{w}$ judaizmie tradycyjnym. $\mathrm{W}$ rekonstrukcjonizmie nie ma tak naprawdę dziedziny ciała i dziedziny ducha, wartości duchowych i wartości cielesnych, pragnień ciała i pragnień ducha. Wszystko to jest wyrazem i odzwierciedleniem natury człowieka. Tendencje, które służą do integracji osobowości i społeczności, jak tendencja do samo-kontroli, lojalności, bezinteresownej miłości, były w tradycyjnym judaizmie przypisywane duszy i uznawano je za aktywności duszy. Tymczasem, jak utrzymuje Kaplan, są to aktywności niepodzielonej natury ludzkiej. Nie ma więc konieczności dzielenia potrzeb człowieka ani też ich deprecjonowania $^{79}$. Wszystkie one jako takie są dobre i służą człowiekowi. Istnieje natomiast konieczność ich uporządkowania i zhierarchizowania, aby nie prowadziły do konfliktu w budowaniu jedności osobowej i społecznej.

Warunkiem wstępnym odnowienia natury ludzkiej, zgodnie z myślą Kaplana, jest uświadomienie sobie niewystarczalności tego, co jest, i poczucie niewspółmierności starań człowieka z przynaglającą Siłą do tego, co powinno być. Kaplan wymiania trzy podstawowe niedoskonałości natury ludzkiej, które powinny stać się przedmiotem odrodzenia (nawrócenia). Pierwszą jest nieumiejętność integracji ludzkich impulsów, nawyków, aktywności społecznych i instytucji w harmonii z tymi uświadomionymi ideałami, które wyrażają obecność Boga w świecie ${ }^{80}$.

souls of men. His sovereignty is therefore dependent on them. Just as the sovereignty of the nation resides in the citizens and their relation to the State, so the sovereignty of God resides in the souls of men and their relation to society". Tamże.

${ }^{79}$ Kaplan tym samym krytykuje pogląd, że źródłem wszelkiego zła, jak utrzymywała tradycja, jest ciało człowieka. To z kolei prowadziło w przeszłości do przeświadczenia, że umartwianie ciała jest dla człowieka korzystne. Wszelkie praktyki ascetyczne miały za zadanie pohamować naturalne potrzeby i pragnienia, co z punktu widzenia rekonstrukcjonizmu było nie tylko bezsensowne, ale i szkodliwe. Możliwe jest $\mathrm{w}$ rekonstrukcjonizmie stosowanie pewnych ograniczeń czasowych lub ilościowych w zaspokajaniu naturalnych pragnień, ale nie w celu ich poskromienia lub wyrugowania, lecz w celu ustawienia ich na właściwym miejscu. Zob. szerzej M. M. Kaplan, The Future, s. 167.

${ }^{80}$ Zob. "When, through introspection and the application of our best knowledge of human nature, we succeed in bringing our impulses into harmony with one another and with the aspirations of our fellow-men to achieve similar integration of personality for themselves, we experience a sense of fulfillment”. („Kiedy przez introspekcję i zastosowanie najlepszej wiedzy na temat natury ludzkiej udało się nam doprowadzić nasze impulsy do harmonii jeden z drugim i z aspiracjami naszych towarzyszy, aby osiągnąć podobną integrację osobowości dla siebie, wtedy doświadczamy poczucia spełnienia"). Tamże, s. 182. 
W tym kontekście boskość jest przez Kaplana rozumiana jako całkowita spójność i pełna integracja. „Przekładając ten atrybut Boga na charakter ludzki, powinniśmy powiedzieć, że jeśli charakter ludzki ma odzwierciedlać to, co boskie, musi być zintegrowany i samo-spójny. To zakłada działającą syntezę indywidualnej samo-ekspresji i społecznej współpracy. Taka synteza jest dlatego dowodem odpokutowania win i owocem efektywnego pojednania"81. Drugi typ niedoskonałości dotyczy braku ustawicznego kształtowania charakteru i dostosowywania się do zmieniających się warunków ${ }^{82}$. Natura ludzka wydaje się ta sama dla każdego człowieka niezależnie od zmieniających się warunków życia. Samo-spełnienie się natury człowieka wymaga dostosowywania się jej do wciąż nowych i innych warunków, aby mogła ona spełniać swoje zadanie. „Kiedykolwiek rozpoznajemy nieadekwatność naszej nabytej osobowości, aby postępować sprawiedliwie w nowych sytuacjach, które tego wymagaja, i próbujemy pokonać przeszkody, które powstrzymują nasze życie od manifestacji tego, co boskie, praktykujemy pojednanie lub powracamy do Boga"83. Trzecim rodzajem niedoskonałości natury ludzkiej jest niewspółmierne wykorzystanie przez człowieka wszelkich potencjalności, które tkwią w jego naturze. Wszyscy ludzie posiadają ukryte możliwości czynienia dobra, które jednak nie przez wszystkich są wydobyte i zaktualizowane dla własnego dobra i dobra społecznego. Maksymalne wykorzystanie wszelkich sił ludzkich wymaga współpracy między ludźmi i jest jednocześnie wyrazem boskiej Siły. "Jest to dowód na to, że nawet kiedy nie ma wspólnego zagrożenia, istnieje możliwość

81 "Transferring this attribute of God to human character, we should say that, if human character is to reflect the divine, it must be integrated and self-consistent. This involves a working synthesis of individual self-expression and social cooperation. Such a synthesis is, therefore, evidence of atonement won and the fruit of effective repentance". Tamże, s. 182-183.

${ }^{82}$ Zob. „The normal development of the individual from dependent childhood to dependable maturity necessitates as part of the law growth a repeated reorganization of one's habits in accordance with the growth of one's powers, the widening of one's social horizons and the acquisition of new responsibilities". („Normalny rozwój jednostki od zależnego dzieciństwa do odpowiedzialnej dojrzałości pociąga za sobą jako część prawa wzrostu powtarzaną reorganizację nawyków zgodnie ze wzrostem siły, poszerzeniem horyzontów społecznych i nabyciem nowych odpowiedzialności"). Tamże, s. 184.

83 "Whenever we recognize the inadequacy of our acquired personality to do justice to the demands of a new situation, and we try to overcome the obstacles that prevent our lives from manifesting the divine, we practicing repentance, or the return to God". Tamże. 
takiej współpracy, aczkolwiek bywa ona w stanie uśpienia"84. Kaplan nazywa ową niedoskonałość "fiksacją", którą traktuje jako formę grzechu indywidualnego i społecznego.

Antropologiczne aspekty myśli Kaplana z pewnością należy uznać za rewolucyjne dla judaizmu. Czy jednak zasadne i właściwe? Proponowane tezy nie tylko różnią się od poglądów teologicznych wypracowanych w tradycyjnym judaizmie, lecz także podważają fundamentalne $\mathrm{i}$ istotne prawdy na temat człowieka. Wprawdzie interesujące jest powiedzenie, że człowiek jest monada, to jednak chcielibyśmy wiedzieć, jak taka monada może być odpowiedzialna za swoje życie w kontekście niezmienności naturalnego prawa (determinizmu). Kaplan przeoczył prawdopodobnie fakt, że w odniesieniu do jednolitości natury każdy czyn etyczny jest aktem wolności, a tym samym, jak pisze „cudem” lub „czymś więcej niż zawieszeniem prawa naturalnego przez Transcendentny Byt". Jak wykazał Kant, wolność jest transcendentalna w stosunku do porządku natury ${ }^{85}$. Ona jest istotnie supernaturalna. Można powiedzieć, że rekonstrukcjonistyczne rozróżnienie między kosmosem a chaosem nie jest dystynkcją między subnaturą a naturą, ani też dystynkcją między dwoma typami natury, lecz dychotomią między tym, co naturalne, a supernaturalne, odrzucenie której jest jedną z zasadniczych przesłanek rekonstrukcjonizmu.

Jak długo Kaplan nie dostrzega, że etyczne zmaganie się człowieka jest aktywnością rzeczywistości kosmicznej, której człowiek jest częścią, tak długo nie wiemy właściwie nic o „boskim aspekcie powszechnego bytu", który jest istotą religii rekonstrukcjonistycznej. W tym punkcie ujawnia się dylemat rekonstrukcjonizmu. Albo wolność jest przez nich traktowana poważnie jako „podstawa duchowego życia człowieka”, w której problem etycznego zmagania się istoty ludzkiej nie jest manifestacją jakiejś kosmicznej siły utożsamionej z boskim aspektem rzeczywistości; albo też etyczne zmagania ludzkie są aktywnością kosmicznego procesu boskości w człowieku, w której wolność stanie się pustą frazą, a etyka uwznioślonym aspektem biologii. Kaplan nie wydaje się świadomy tego problemu i utrzymuje z entuzjazmem, że wolność i immanentna etyka kosmicznego mechanizmu, która działa $\mathrm{w}$ celu realizacji

${ }^{84}$ This is evidence that, even when there was no common danger, the possibility of such cooperation existed, although it lay dormant". Tamże, s. 185.

${ }^{85}$ Zob. E. Kant, Kritik der reinen Vernunft, Elementallehre, cześć II, rozdz. II, księga II, akapit III. 
dobra, są możliwe do pogodzenia. W mniemaniu Kaplana, gdziekolwiek człowiek dokonuje etycznych czynów, działa zarówno w wolności jak i pod presją jakiejś kosmicznej siły lub impulsu. To prowadzi do absurdalnego stwierdzenia, że człowiek jest i wolny, i zdeterminowany (nie w znaczeniu: zdeterminowany cieleśnie, wolny duchowo, lecz całkowicie wolny zarówno zarazem zdeterminowany w swojej cielesności i duchowości). Człowiek, według Kaplana, pragnie dla siebie zbawienia na tym świecie, lecz ani poszukiwanie zbawienia ani wybór sposobu jego realizacji nie są całkowicie wolne, ponieważ „natura ludzka jest częścią większego świata natury"86. Oczywiste jest, że człowiek nie może być odpowiedzialny za to, co nie jest wolnym, lecz zdeterminowanym przez kosmiczny bodziec działaniem.

Widać wyraźnie, że rekonstrukcjonizm uwikłał się w panteizm. Każda forma panteizmu jest destrukcyjna dla jednostki. Jednostka jest zwykłą fikcją lub ułudą. Nie ma tu miejsca na żadną indywidualność, jej znaczenie lub wartość. Panteizm jest z konieczności deterministyczny. Nie ma w nim miejsca na powinność, lecz jedynie na konieczność. Cała rzeczywistość jest manifestacją natury boskiej, którą jest to, co jest, a nie to, co powinno być. Ludzkie aspiracje i działanie są częścią większej całości. Są one wyrazem rzeczywistości kosmicznej, która nie może być zrealizowana przez iluzoryczną indywidualność, nazywaną zazwyczaj osobowością. Skoro nie ma w panteizmie ani wolności, ani sensu dla osobowego istnienia, wówczas dobro i zło stają się bezprzedmiotowe. Wszystkie powyższe implikacje odnoszą się do rekonstrukcjonizmu. Jeśli Bóg jest w człowieku i człowiek jest w Bogu, osobowość ludzka nie może być nieredukowalną monadą, światem w sobie, niezależnym punktem odniesienia, o czym wielokrotnie mówił Kaplan. Jeśli ludzkie zmagania są „objawianiem się” w człowieku aktywności kosmicznego pędu, jeśli odzwierciedlają kosmiczną strukturę rzeczywistości, jeśli są popędami i powszechnymi prawami - jak rozumie to rekonstrukcjonizm - wówczas wolność nie może być "zakorzeniona w duszy” (co starał się dowieść Kaplan, aby uzasadnić etykę). Rekonstrukcjonizm nie dostrzega tych sprzeczności i niespójności systemu myśli. Nie ma żadnego uzasadnienia dla logicznych implikacji takiego stanowiska.

Pomimo faktu, że natura ludzka jest częścią większej natury (przynajmniej w sensie biologicznym), wydaje się niedorzecznością dopatry-

86 "human nature is a part of the larger world of nature". M. M. Kaplan, Judaism without, s. 119. 
wanie się w naturze ludzkiej manifestacji struktury kosmicznej rzeczywistości, a tym samym samego Boga. Propozycja Kaplana nie jest, jak sam głosił, „tryumfującym egzorcyzmem na przygnębiające credo Bertranda Russella: Krótkotrwałe $i$ bezsilne jest życie człowieka"87. Należy przyznać rację Berkovitsowi, że z naukowego punktu widzenia stanowisko Russella ma większy sens niż Kaplana. Metoda rekonstrukcjonizmu, która polega na przejściu od wyższych aspiracji człowieka do struktury powszechnej rzeczywistości, jest równoznaczna z antropomorfizacją kosmosu, któremu przypisuje się ludzkie wartości i znaczenia. W systemie Kaplana nie dochodzi na pozór do urzeczowienia człowieka lub Boga, lecz do przypisania naturze (kosmosowi) cech ludzkich. Kosmiczne korelaty są w myśli Kaplana niczym innym jak tylko projekcją ludzkich pragnień i oczekiwań przeniesionych na płaszczyznę kosmiczną. Stąd zasadnicze rozróżnienie między kosmosem a chaosem. Z punktu widzenia natury nie ma żadnej różnicy między światem zwierząt i roślin, a światem ludzkim jako wyższym wyrazem rozwoju natury. Kiedy Kaplan określa konstruktywne siły natury „kosmicznym pędem” i utożsamia chaos z tym aspektem rzeczywistości, który może zniweczyć aspiracje ludzkie, przedstawia czysto ludzką wartość pojęć w zdeterminowaniu natury rzeczywistości. Poza świadomością ludzką i dążeniami człowieka możemy odnaleźć jedynie fakty, lecz nie wartości. Życie wszechświata, którego z pewnością jesteśmy częścią i które jest „najwyższą wartością, ponieważ z niej wyprowadza się wszystkie inne wartości", jest rekonstrukcjonistyczną projekcją ludzkiego „entuzjazmu życia” na kosmiczny wymiar.

Kiedy rekonstrukcjonizm mówi o Bogu, porusza się w kole transnaturalnym, wychodząc od człowieka i kończąc na człowieku. Można powiedzieć, że teologia przerodziła się tutaj w swoistą antropologię i socjologię. Jest to szczególnie widoczne wówczas, kiedy Kaplan dokonuje reinterpretacji człowieka stworzonego na podobieństwo Boga (teoria kreacji). Jak wykazaliśmy w poprzednich analizach, jest „coś w naturze życia", co wyraża się w istnieniu osobowości ludzkiej i wywołuje $\mathrm{w}$ człowieku potrzebę ideałów i pragnienie zbawienia. Utożsamienie tego "czegoś" z Bogiem prowadzi do swoistego rozumienia tradycyjnej prawdy o stworzeniu człowieka na podobieństwo Boga, ponieważ takie utożsamienie zakłada, że jest "coś boskiego w ludzkiej osobowości, co odgrywa rolę narzędzia, za pomocą którego twórcze życie wszechświata

87 "triumphant exorcism of Bertrand Russell's dismal credo: Brief and powerless is man's life". M. M. Kaplan, The Meaning of God in, s. 27. 
dokonuje ewolucji ludzkości" ${ }^{\prime 8}$. Prawdą jest, że aspekt rzeczywistości odpowiedzialny za rozwój ludzkiej osobowości jest ukazany jako „twórcze życie świata" tylko dlatego, że człowiek wiąże wartość z osobowością. "Coś w naturze życia" jest uznane przez Kaplana za Boga tylko dlatego, że człowiek uznaje swoje własne ideały i dążenia. Można to uznać za próbę deifikacji wartości ludzkich. Bez wątpienia Kaplan dostrzega w ludzkiej osobowości coś boskiego. Jak widać, w rekonstrukcjonizmie mamy do czynienia z projekcją ludzkiej osobowości na wszechświat, na „coś w naturze życia”, co jest odpowiedzialne za jej rozwój. To z kolei graniczy z deifikacją osobowości ludzkiej. Nie jest to zatem próba odnalezienia obrazu Boga w człowieku, lecz usiłowanie odnalezienia obrazu człowieka w Bogu. Prowadzi to do ubóstwienia człowieka a jednocześnie do ubóstwienia kosmosu. Mamy w rekonstrukcjonizmie, świadomą lub nie, sytuację, w której idea Boga została skonstruowana na podobieństwo człowieka. W podejściu Kaplana Bóg nie jest twórcą religii. To człowiek z całym swoim „bagażem” kulturowym „tworzy” Boga ${ }^{89}$.

Podejście Kaplana nie jest już tylko deifikacją człowieka i wszechświata, lecz także antropomorfizacją (a tym samym personifikacją) sił i procesów obecnych we wszechświecie. Tym samym nastąpiła relacjonizacja Boga. Nie ma żadnych wątpliwości, że teologia rekonstrukcjonistyczna ze swoim transnaturalizmem jest formą panteizmu. $W$ świetle krytycznych analiz i prób oceny należy określić charakter tego panteizmu. W historii filozofii wyróżniamy panteizm akosmiczny i ateistyczny ${ }^{90}$. Akosmicznym panteizmem był panteizm Spinozy, który utożsamiał naturę z Bogiem. Spinoza właściwie nie zakwestionował Boga, lecz naturę. Rekonstrukcjonizm nie prezentuje tego typu panteizmu ani też żadnego innego, które ma swoje inspiracje w metafizyce. Chcąc określić propozycję rekonstrukcjonistyczną pod tym względem, najwłaściwsze byłoby nazwanie jej „panenteizmem rekonstrukcjonistycznym”, ponieważ Bóg

88 "there is something divine in human personality, in that it is the instrument through which the creative life of the world effects the evolution of the human race". M. M. Kaplan, The Meaning of God in, s. 89.

${ }^{89}$ Por. H. C. Weisberg, Mordecai M. Kaplan's Theory of Religion, w: I. Eisenstein, E. Kohn (red.), Mordecai M. Kaplan: An Evaluation, New York 1952, s. 187.

${ }^{90}$ Istnieją różnorodne formy panteizmu. Niekiedy wyróżnia się panteizm skrajny (Bóg i świat to formy bytu pierwotnie ze sobą tożsame) i panteizm umiarkowany (dostrzega częściową różnicę między Bogiem a światem: świat byłby składowym elementem natury Bożej - wtedy nazywamy go panenteizmem - lub Bóg byłby fragmentem kosmosu). Zob. szerzej: S. Kowalczyk, Filozofia Boga, Lublin 1993, s. 22-24. 
nie jest tu ani całkowicie tożsamy z wszechświatem, ani też świat nie jest składowym elementem natury Bożej, lecz Bóg jest fragmentem wszechświata (Siłą lub Procesem kosmosu, obok którego istnieje nieprzeniknięty przez boskość chaos jako część natury).

Dla Kaplana punktem wyjścia nie jest widzenie całości natury i utożsamienie jej z Bogiem, lecz człowiek, jego aspiracje, impulsy i wartości. Jak dalece człowiek akceptuje swoje cele i impulsy, tak dalece są one zapośredniczone w kosmosie i urastają do miana kosmicznego pędu, objawiając strukturę rzeczywistości. Uznanie tych aspektów rzeczywistości za boskie jest tym samym utożsamieniem Boga z kosmosem, lecz z kosmosem ukształtowanym na podobieństwo człowieka i jego pragnień. Rekonstrukcjonizm nie powinien zatem być określany znanym nam do tej pory panteizmem, ponieważ paradoksalnie jest najbardziej radykalną formą antropomorfizmu, który z założenia miał być przez rekonstrukcjonizm odrzucony. Uwzględniając sugestie Berkovitsa należałoby nazwać go raczej „panantropomorfizmem”91. Wbrew zapowiedziom Kaplana rekonstrukcjonistyczna wizja człowieka osiągnęła nie rekonstrukcję, lecz dekonstrukcję tradycyjnej antropologii żydowskiej. Warto zauważyć, że tego rodzaju transnaturalna antropologia, chociaż żydowska, nie odpowiada żadnemu dotychczasowemu obrazowi człowieka w judaizmie. Można zatem stwierdzić, że jest żydowska, ale nie judaistyczna. Bliższa jest ideom New Age niż duchowi żydowskiemu.

\section{ANTHROPOLOGICAL ASPECTS OF JEWISH RECONSTRUCTIONISM}

\section{SUMMARY}

In evaluation of present times two phenomena there are evident, which reciprocally condition each other. The first is total renunciation of religions of previous generations and decline in religious practices (this does not always mean questioning the existence of God), the second involves divergence from traditional for certain religions understanding of God and man, in which people still believe. Traditional understanding of human being in Judaism (theory of creation) seems to be for contemporary Jews more and more an aberration, something the humanity has already outgrown.

Many contemporary Jewish philosophers faced the challenge of overcoming this impasse by creating such a concept of man, which - in their opinion -

91 "Pananthropomorphism” - zob. E. Berkowits, Major Themes in Modern Philosophies of Judaism, New York 1974 s. 182. 
would be more adequate and helpful in revival of a true faith in God. Among these suggestions we find a concept by Kaplan, who is a founder of the Jewish reconstructionism. Reconstructionistic concept of man seems, like no other, an alternative to theistic understanding of human creation. Kaplan's point of view is thus connected with negation of traditional faith in God, the faith which carries its existential and scientistic cause.

The starting point for the reconstructionist involves indeed the reconstruction of the traditional Judaism, which takes place basing on ideas taken from social and natural sciences. With such an approach it is not the faith, but the knowledge which provides the criterion of truthfulness of the concept of man. Without a doubt, the reconstructionism crossed the borders of Jewish theism and placed itself in opposition to it.

The Judaism in the Kaplan's understanding is a civilization and not a religion, as it has been held up till now. The religion is only one of many elements of a civilization and it is not the most important, most significant and unconditional one. The concept of man in reconstructionism not only may change, but has to be changing like other elements of the Jewish civilization. From now on, one does not have to be a theist to remain a believer in Judaism. This is an absolute novelty in the Jewish world. A reconstructionist does not accept the supernaturalism and, thus, he does not believe in divine origin of the Tora, nor the theory of creation, miracles, eternal life in the other world. The postulate of a non-personal God is a result of the negation of the supernaturalism and of the traditional Jewish soteriology. Man is not just natural being but transnatural one without supernatural element.

The performed analyses permit to state (but not to conclude firmly), that Jewish reconstructionism is a specific Jewish theory, a way of living for a certain group of Jews, but it is not a Judaism. The transnatural conception of human being, although Jewish, does not conform to the Jewish concept of man, moreover, nor it does conform to monotheistic theory of creation. Such vision of God and man leads to a modern Jewish religion of a faithless character, in which every Jew will be able to identify himself/herself. The Kaplan's system, which represents a result of an intentional reconstruction and revaluation of the traditional Judaism, in fact becomes a deconstruction and a devaluation of Judaism.

The present paper reveals that this phenomenon fulfils every condition to be regarded as representing the Jewish New Age. A fundamental characteristic of the New Age movement is a pantheism understood as a faith claiming that everything is God and God is in everything. In its base a conviction lays, that all the people are the unity and the feeling of anybody's existence separate the world and other creatures is just a recognition of one's ego by own mind. 